\title{
Experiences of Students with Special Needs on Sport Education Model
}

\author{
Neşe Saraç Oğuzhan ${ }^{1}$, Deniz Hunuk ${ }^{2}$ \\ ${ }^{1}$ Guney Secondary School Denizli, Turkey \\ ${ }^{2}$ Faculty of Sport Science, Pamukkale University, Turkey \\ Correspondence: Deniz Hunuk, Faculty of Sport Science, Pamukkale University, Turkey.
}

Received: December 10, 2017

doi:10.11114/jets.v5i13.2853

\author{
Accepted: December 29, 2017 Online Published: January 10, 2018 \\ URL: https://doi.org/10.11114/jets.v5i13.2853
}

\begin{abstract}
The aim of the study was to examine the experiences of the students with special needs on the sport education model (SEM). In this research, action research method was used (Mertler, 2009). In the scope of the research, a mini-volleyball season was practiced with SEM in a secondary school $-6^{\text {th }}$ grade - for 16 weeks. The physical education teacher has 6 years of teaching experience and for the first time she has tried SEM at her school. In total, there were 12 participants in the research; 7 of them ( 3 girls, 4 boys) with special needs who have attended to this lesson and were chosen with purposeful sampling, and the other 5 students who were also the trainers and the captains of the teams. Collecting data includes the teacher's reflective diary, weekly discussions with the expert, two focus group interviews with the students and volleyball skills observation forms. Skill observation forms were analyzed by descriptive statistics and the other data analyzed by content analysis. The findings of the study were gathered under three themes: (1) the effect of the SEM on the skill levels of the students with special needs; (2) the students' opinions on the non-player roles; and (3) the relationships of the students with special needs with their teammates. As a result, it has been seen that, the SEM, giving active roles to the students with special needs in the team in accordance with their talents and interests has promoted their active participation in class, motivation and socialization.
\end{abstract}

Keywords: sport education model, action research, special needs, model-based approach

\section{Introduction}

In the last decade, the sport education model (SEM) has received considerable interest in sport pedagogy. Studies on the SEM showed that it is a new, effective and creative approach to sport education within physical education at school and that students are very fond of it (Araújo et. al, 2014; Vidoni \& Ward, 2009; Wallhead \& Ntoumanis, 2004).

Model-based practice and SEM in particular has been included in the guidelines of Secondary School and High School Physical Education Curriculums for the first time in 2006 and also SEM has been the basis of the Secondary School Sports and Physical Activity Course which has been given since 2013 (MoNE, 2013). However, Ince and Hunuk (2010) stated in their study that Turkish experienced physical education teachers use of teaching styles and related value perceptions are not meeting the new physical education program requirements of using learner centered approaches and teaching methods. In the Turkish context there is a limited number of studies have been done on the SEM. In these studies, the effects of the SEM on the university and secondary school students' cognitive, affective, psychomotor levels, and attitudes towards physical education and sport were examined (Çelen, 2012; Koyuncuoğlu, 2015; Doydu, Çelen \& Çoknaz, 2013; Doydu \& Çoknaz, 2013; Doğu \& Altay, 2010). The results of these studies correspond with the view in the literature that the model is effective in promoting students' participation in physical education (Wallhead \& O'Sullivan, 2005) and SEM introduces students to a range of roles and responsibilities that extend their involvement in the sporting experience beyond that of player (MacPhail et al., 2005).

Sport Education Model (SEM) is a curriculum and instructional model that will help students become more active and healthy throughout their lives, and support their real-life experiences in an amusing and comprehensive way. The SEM is instructive in providing students cognitive, affective and psychomotor traits in physical education. For SEM's functionality, the role of the teacher and the roles to be given to the student must be well known and internalized. However, seeing the impression on the students with differences when player and non-player roles given will be helpful for the teachers in the implementation process (Siedentop, Hastie \& Van Der Mars, 2011).

The main goal of the model is to train competent, literate and enthusiastic sports person. A competent sports person 
understands and implements the skills and strategies necessary for participating in games. A literate sports person understands and values game and sport rules, requirements and traditions. Thus, the individual becomes a decent participant, a sport fan and a conscious consumer as an audience. An enthusiastic sport person seeks to protect and preserve the sport culture, to increase its value and beauty and becomes a participant (Siedentop et. al, 2011).

The SEM appears to provide some benefits for physical education students and teachers. The benefits for students include a high-level of personal investment, more opportunities for women to participate and for low-skilled students, and higher success level. For the teachers, it includes a more autonomy supportive environment compared to direct teaching, focusing more on personal needs of students and a refreshed interest in teaching. When used within the context of lifetime leisure activities, the sport education model provides an effective alternative to teaching physical activity as part of a healthy lifestyle considering more traditional approaches (Mohr, Townsend, \& Pritchard, 2006).

It is emphasized in the studies carried out with the students with special needs that not only competent, literate and enthusiastic sports person, but also individuals with the sense of special needs can be educated through the SEM in society (Foley, Tindall, Lieberman, \& Kim, 2009). It is clear that the SEM is very useful and brings out a grand potential when it is adapted to the students with special needs in a physical education lesson (Presse, Block, Horton, \& Harvey, 2011). For example, a study showed that the SEM practice of students with visual disability is effective in providing an authentic sporting experience (Fittipaldi - Wert, 2009). Alternatives for the children with special needs in the SEM process should be particularly considered. When implemented and evaluated correctly, students with special needs can be successfully involved in the SEM as competent, literate and enthusiastic sport persons along with their peers (Tindall \& Foley, 2011).

In general, in a physical education class, some of the students do not participate or want to participate in the lesson due to their limitations. However, in the sport education model, every student can participate in the lessons while their limitations are taken into account. Students who cannot participate or want to participate in classes due to their physical problems can be involved in lessons by giving them other duties than playing. In addition, students who are deemed to have a lower level of ability than other students in terms of the nature of the sport branch to be implemented can also be given active duties in accordance with their other abilities (İnce et. al, 2010).

Besides that the positive and beneficial results of the SEM on the teachers and the students are well known in the literature (Hastie \& Sinelnikov, 2015; Çelen, 2012), there is a limited number of studies on the students' with special needs experiences during the SEM process, their opinions about their roles, its effects on their skill development and social competence. Therefore, the aim of this study is to examine the experiences of the students with special needs regarding the sport education model.

\subsection{Theoretical Framework}

The model-based approach focuses on the teaching and learning characteristics of specific curriculum and instructional models, on their application needs and on changes. The model-based approach encourages the use of various teaching models throughout a physical education curriculum, each with its unique and distinctive learning outcomes and its alignment of learning outcomes with teaching strategies and subject matter (Lund \& Tannehill 2005, Lund, Gurvitch, \& Metzler, 2008). This approach also provides opportunities for the teacher to teach the acquisitions in numerous fields (psychomotor, affective, cognitive) in depth during the course through student-centered approaches. Using model-based teaching practices in physical education and sports raises the effectiveness of teaching permanently (Metzler \& Mc Cullick, 2008). In the literature, there are several well-researched and well-developed models already exist in models-based approach to physical education. In this study, Sport Education Model is used as one of the model-based approach to physical education.

\section{Method}

In this research, action research method was used. The action research is defined as the research of teachers to develop their own practices, ways to identify their needs, and methods to improve their efficiency in teaching (Mertler, 2009). Action research is a remarkable and attractive choice for researching teachers, school administrators and other members in teaching and learning environment. It provides new information and insights into how practitioners can improve their practice of education and solve the significant problems they may face in class or at school (Mills, 2011).

The action research studies carried out until today on general education and physical education demonstrate that to have a lens as teacher as a researcher or action researcher have an important part in solving the problems (Alagül \& Gürsel, 2014). Based on the action research, Mertler's cycle of action research was used in this study. According to Mertler (2009), an action research consists of three stages: planning, acting, developing and reflecting.

Planning: The planning stage of an action research begins by identifying the problem to make a research on that occurs within the class. The researcher, along with the identification and classification of the problem, collects information 
about it in the class environment. Then he/she develops a research plan by reviewing the relevant literature about the problem. In this study, the researcher decided to use SEM in her class in order to increase the participation of the students with special needs in their own school environment, reviewed the related literature and prepared a yearly plan accordingly.

Acting: The acting phase of an action research consists of the steps of data collection and data analysis. In this study, the researcher practiced the SEM for 16 weeks with mini-volleyball and used both qualitative and quantitative data collection methods in the process.

Developing: Developing an action plan is in fact a sign that something else will be used in the future. At this stage of the action research process, the researcher tries to answer the following question: What should I do now after what I have learned from this research? (Mills, 2011). The researcher shared the results of the data analysis with the expert (the $2^{\text {nd }}$ writer of the research) at the university, took her opinions and put the last touches on her weekly plans. The expert played a role making teacher's work easier in terms of the modeling by sharing information, the ways that going well in the lesson and discussing the ways that going wrong. The researcher has developed the next week's action plan with the opinions of the expert and student reflections obtained throughout this process. At this stage, she also planned to give different roles and responsibilities within the model to the students with special needs by using the SEM again for the next school year.

Reflecting: This process consists of describing and sharing findings, reflecting on the process and reporting steps. At this stage, the researcher shares the results of the research with the teachers from other branches at school and with the supervisor/expert and other faculty members at university.

\subsection{Participants}

In the scope of the research, a mini-volleyball season has been practiced with the SEM in a secondary school - 6th grade - for 16 weeks. Seven students ( 3 girls, 4 boys) have participated in the research with special needs who have attended to this lesson and were chosen with the purposeful sampling method. It has been seen that two of them have physical disabilities and all of the students have difficulty in learning and low-levels of skills. The fact that the students' levels of the special needs and disabilities are not high, and receiving education together with their non-disabled classmates makes this class a inclusive one. In addition, with focused group interviews were made with 5 students in leading positions serving as trainers and captains, and training in the same teams with these students, their experiences during the process of the involvement of the students with special needs in the lessons were analyzed. All of the participants' names are pseudonym to guarantee their privacy and to distinguish their views.

\subsection{The Stance of the Researcher}

The physical education teacher (the $1^{\text {st }}$ writer of the research) who has been working at this school for 3 years has 6 years of teaching experience and has tried the SEM at her school for the first time. The researcher is also experienced in graduate level teaching models and qualitative research. Implementing the model at school, she gets the practitioner and researcher position who shares all of the negative and positive situations she faces concerning the students and the modeling. The teacher, as the researcher in this study, used her insights and interpretations as data by implementing the SEM model, playing an active role in the process and avoiding her own bias and assumptions. The researcher was able to make observations through the process, not only instantaneously. She has also received weekly feedbacks from expert (the $2^{\text {nd }}$ writer of the research) who is experienced in the SEM during the SEM mini-volleyball season.

The second researcher has the role of "expert" in this study. At the same time, she made focus group interviews with the students and came together weekly with the first researcher to participate in the interviews on the model's effects and its implementation at the school. The second researcher has participated in many different studies and courses with the physical education teachers before and is experienced in the SEM. Besides, she is experienced in teaching on qualitative research at undergraduate and graduate levels.

\subsection{Data Collection Tools}

Data collection includes the teacher's reflective diaries, focus group interviews made with the students, weekly discussions made with the expert and skill observation forms regarding volleyball.

The teacher's reflective diaries: The teacher has recorded the observations he/she made on weekly basis during the SEM process and the participation of the students with special needs in the SEM. There are 25 pages in total.

Focus group interviews: Following the implementation of the SEM, a focus group interview was made with 7 students who had special needs concerning their experiences during their participation in the lesson. In this process, the students were asked questions about what they liked/disliked about the SEM, their roles and experiences with their team/classmates. In addition, focused group interviews were made with 5 students in leading positions serving as 
trainers and captains, and training in the same teams with the students with special needs. In these interviews, the experiences of the students with special needs during the lesson were analyzed. The focus group interviews lasted approximately 45 minutes and were recorded with voice recorder.

The teacher's weekly discussions with the expert: In this process, the teacher met with the expert on a weekly basis who is an expert on the subject and gave information about the process before they made discussions on it. During the discussions, the difficulties encountered in implementing the SEM and solutions, the involvement of the students with special needs, and the stages of the action research were frequently highlighted. The discussions were recorded with voice recorder and transcript before analysis.

Volleyball Skill Observation Form: The volleyball skill observation form was developed by Çelen (2012) and includes overarm pass, bump pass, service and spike skills in volleyball. Volleyball skill observation forms have been rated as 1 "Never", 2 - "Rarely", 3 - "Sometimes", 4 - "Frequently" and 5 - "Always". The score of "5" given during the observation of a critical behavior indicates that the behavior has been acquired or observed in accordance with the technique while the score of "1" indicates that the behavior has not been acquired or observed.

\subsection{Data Analysis}

Before the qualitative data analysis, the audio records of the interviews/discussions made with the researchers and participants were transcript and the created text files were computerized. The qualitative data were analyzed using constant comparative content analysis (Glaser \& Strauss, 1967). Content analysis involves the search for meaningful events within the data, deciding on themes to define the data as a whole, discovering the relationships between them and assigning descriptive codes (Miles \& Huberman, 1994). Pre-test and post-test scores of students' skill observation forms were analyzed by Wilcoxon signed rank test.

\subsection{Trustworthiness}

The fact that the researcher is in a teacher/practitioner position, her prolonged engagement with the students and objective involvement increases the trustworthiness. Specifying the position of the researcher, receiving an expert opinion and using multiple methods of data collection-data triangulation- (focus group interview, reflective diary, weekly discussions with expert) are among the factors increasing trustworthiness as well.

\section{Findings}

In general, it was observed that the students with special needs enjoyed the SEM, were pleased to team up and take a lesson focusing on mini-volleyball. Further, as a result of the content analysis, the findings of the study were gathered under three themes.

Theme-1. The SEM's effect on the skill levels of the students with special needs: According to the results of the skills observation forms, it is observed that at the beginning of the process the skill levels of the students were low and their skills in volleyball have improved at the end of the process.

Table1. Comparison of pre-test post-test scores of the students following the volleyball skill observation forms

\begin{tabular}{|c|c|c|c|c|c|c|c|c|}
\hline \multirow{2}{*}{$\begin{array}{c}\text { SKILLS } \\
\\
\text { NAMES }\end{array}$} & \multicolumn{2}{|c|}{$\begin{array}{l}\text { Overarm } \\
\text { Pass }\end{array}$} & \multicolumn{2}{|c|}{ Bump Pass } & \multicolumn{2}{|c|}{ Spike } & \multicolumn{2}{|c|}{$\begin{array}{l}\text { Underhand } \\
\text { Service }\end{array}$} \\
\hline & 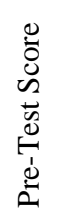 & 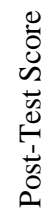 & 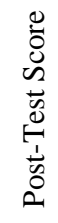 & 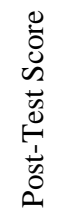 & 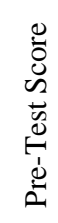 & 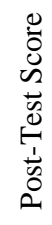 & 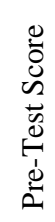 & 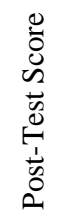 \\
\hline Cenk & 22 & 35 & 32 & 35 & 21 & 31 & 31 & 40 \\
\hline Necip & 15 & 27 & 18 & 26 & 14 & 23 & 24 & 30 \\
\hline Gökhan & 18 & 20 & 17 & 23 & 18 & 22 & 29 & 30 \\
\hline Tolga & 14 & 20 & 13 & 24 & 16 & 20 & 33 & 39 \\
\hline Bilge & 14 & 21 & 16 & 24 & 8 & 18 & 20 & 23 \\
\hline Gülhan & 11 & 27 & 18 & 29 & 14 & 24 & 19 & 36 \\
\hline Duru & 10 & 21 & 7 & 18 & 8 & 16 & 16 & 22 \\
\hline
\end{tabular}

$\mathrm{p}<.05$ 
According to results of the Wilcoxon signed rank test, there is a significant difference in the skills of overarm pass $(\mathrm{Z}=2,36 ; \mathrm{p}=.018)$, bump pass $(\mathrm{Z}=2,38 ; \mathrm{p}=.017)$, spike $(\mathrm{Z}=2,37 ; \mathrm{p}=.018)$ and underhand service $(\mathrm{Z}=2,36 ; \mathrm{p}=.018)$ of the students with special needs from the pre-test to post test scores when these scores are compared following volleyball skill observation from Wilcoxon signed rank test at the end of the SEM process.

In the focus group interviews made with the students and in the teacher's reflective diary, it was stated that the skill levels of the students with special needs improved and they provided more contribution to the game/match with the following words:

'We held a match with adapted rules. Duru served. It was a side-out and her team won the rally. Her friends applauded her for a long time.' (The teacher's reflective diary- the $6^{\text {th }}$ week)

"One day, I came to class early. He was practicing overarm pass at the wall away from the corner, the team. He practiced bump pass, served, tried it again and again. I called him, Cenk, and said that we would start now and not to tire himself. And he said 'I do that everyday. I count to one hundred and then I stop.'” (The teacher's reflective diarythe 9th week)

Team coach Sinan explained that his teammate Gökhan with mild mental retardation had improved his skills during the SEM with following words: "At first, I thought that Gökhan had difficulty in performing many skills and could not learn them even if we tried again. Then I noticed that he was better at overarm and bump pass at the training week. We practiced together during the entire training. He was the one directing the ball to me with the most successful overhand passes. Then I spiked the balls, so we made our team the champion." (Focus group interview - Sinan)

"Now I can play, I can serve. I have vascular contraction in my left arm, it's something congenital. But I realized that I don't have to use my left arm, though I did use it. I couldn't do a overhand pass, now I can do it with one hand. I couldn't grab the ball with both of my hands and serve. Now I can start the game with one hand. I mean, I can do all the moves that I thought I couldn't do before." (Focus group interview - Tolga)

Gülhan, who had low skill level, expressed that learning a skill throughout the term with the SEM has improved her skills with following words: 'Now I understand volleyball much better. We would practice it only once in two or three weeks. Now we practiced volleyball throughout the term. I can serve, my skill level has improved." (Focus group interview-Gülhan)

Theme-2. The students' opinions on their non-player roles: In the scope of the SEM, the students with special needs were given non-player roles as well as each student in the classroom. Most of the students with special needs stated that they fondly/willingly fulfilled these roles, maintained their roles outside the school and could have the same ones again.

Tolga, Duru, Cenk and Gökhan were the ones that I had great difficulty in getting their attendance to lesson before. They raised their hands and said that they wanted to be first aid specialist, ball boy/girl or captain. They wanted to share the task immediately and were thrilled when I told them about the matches, the awards and festivals" (The teacher's reflective diary- the $1^{\text {th }}$ week)

Cenk, who has learning difficulty, took the role of assistant/co-coach and expressed he enjoyed his role in the focus group interview with following words: "I took the trainer role. But there were two trainers in our team. I was enjoying my role but having two trainers in a team was a problem. She would take on the tasks that I wanted to fulfill myself. My friends wouldn't let me join in games before. Now I teach them to play after school." (Focus group interview-Cenk)

"There was no injury. I did not do much. We learned how to help them in case of injury. For instance, we would inform the teacher first and prepare first aid materials. When our teacher comes, we would help her/him." (Focus group interview - Gülhan)

In this process, the teacher made field observations on how the students with special needs internalized their roles and took relevant notes. The notes are as follows written by the teacher on her diary about Bilge who took the role of first aid specialist after a crash occurred in the 5th week of the class: "One of the students who crashed got up and began to run to the school. I felt frightened and headed to Bilge thinking she might be injured. She took the band-aid from her bag and asked me 'I'm the first aid specialist and my band-aids are in my bag. Could you apply them for me?'. At that moment, I have seen that Bilge fulfilled the responsibilities of her role." (The teacher's reflective diary- the $5^{\text {th }}$ week)

Theme-3. The relationships of the students with special needs with their teammates: The students stated that it was exciting to take part in a team and required responsibility. In addition, the students with special needs also expressed that they became more socialized with their teammates in or out of the school with the implementation of SEM at their school. The other students who have the roles of coach or captain said that they communicated more with the students who have special needs in and out of the class and developed their own coaching and leadership skills as helping them improve their own skills. 
One of the trainers of a team, Aytaç stated in the focus group interview that he also spent time with his teammate Tolga, who has physical difficulty, out of the class to improve his team and Tolga's skill level with following words:

"We played volleyball with Tolga out of school. We live close to each other. I trained him. We played three days a week, every week. My intention to play with him was for our team to win and Tolga's improvement. I trained with him because I wanted to make him better."

The teacher played a great role as well in Aytaç's accepting Tolga, who is in fact his friend, and his practicing with his friend out of school. The teacher emphasized the importance of being a team and acting together for weeks within the SEM, stated that personal achievements contribute to team achievements and wrote down the situation on her diary in the 3rd week as follows:

I matched the students with special needs with their friends whom they can train easily with. When I talked to the children, I heard them saying 'We're good, we will train more together, until we can'. My student who has physical difficulty was unwanted by his/her teammates. Then we talked about it and moved on with the motto 'Their success is team's success." (The teacher's reflective diary, the $3^{\text {th }}$ week)

At the end of the term, the students had better relationships with each other in the classroom as well and explained that they don't conflict with each other on some situations like before in physical education classes with the following words:

'Our team's name is Hawks. We play at the other field of the school when the court is not available. We drew a court line there and made a new from rope. I practice there with my teammates. Before now, we couldn't do activities as a class. We would fight while arranging the teams, arguing with each other like 'Our team is more powerful than yours" or because one dislikes the other so don't want him/her in the team. Therefore the game was left unfinished or ended before it began. Now each person has a certain team and trying to make it better. We can hold a match as a whole class because the teams are certain already. We decide to hold a match right away with our sister team Risings at the back field of the school, also call the referees from other teams. Nobody make an objection." (Focus group interview-Merve)

The SEM process has improved not only the skill levels of the students with special needs, but also the coaching and leadership skills of the other students serving as coaches and captains in the teams gradually with the lessons. Particularly, Merve who is a co-trainer with her peer with special needs stated that her coaching and leadership skills have improved with the following words:

"I liked the role of coaching. It was nice to play as a team and improve ourselves together. My leadership skills have also improved. I made my teammates perform better by fixing the mistakes. My skills are way better comparing to the first lessons. We were two trainers. I tried to do everything because I liked my role. I tried to make training plans by myself. Now I can make a simple plan even if in a different branch. For instance, I can lead the stretching trainings in football. After all, we ask our teacher in case of the things we don't know, then we do it together. And I can lead the given trainings. (Focus group interview - Merve).

\section{Discussion}

The model-based approach, which is the theoretical framework of the research, will provide an advantage in terms of the teacher's awareness of student expectations during the modeling process who worked previously with the students or knows the student group. The adaptations on the model made by the teacher have improved the intellectual skills of the students. Model-based approach is an effective way to reveal the expectations of every lesson and make the students earn achievements (Metzler, 2011).

In terms of the theory, the teacher was able to define the students and the environmental conditions, thus decided on the model and the branch to be implemented with the model considering their requests. Apart from the change in all students, the change in the students with special needs drew more attention. The attendance of the students with special needs was provided by making adaptations and changes according to their requests. These adaptations and changes include the way of the lesson, the games, the rules of the games and the roles. All of the students were made to think when the changes in the activities of the students with special needs were shared with the team and the new ideas were suggested. The notes written down to the reflective diary after every lesson demonstrates the expectations and the achievement levels of the students. The expert (the $2^{\text {nd }}$ researcher) has supported the study by making a conclusion in the things to be done on a weekly basis in the discussions. Conveying her experiences, her students' experiences regarding the model and planning the next class or term considering all the outcome throughout the SEM process, the teacher emphasized the importance of using action research to specify the effectiveness of the model.

In line with the aim of the study, the experiences of the students with special needs regarding the SEM were analyzed during the process. In this study, the 16-week season of mini-volleyball practiced with the SEM, there are 7 students (3 girls, 4 boys) with special needs. In addition, with focus group interviews were made with 5 students in leading 
positions serving as trainers and coaches, and training in the same teams with these students, their experiences during the process of the involvement of the students with special needs in the lessons were analyzed. It is going to be discussed separately under the themes in the discussion section below.

Theme-1. The effect of the SEM on the skill levels of the students with special needs: The difference between the pre-test and post-test results in the skill observation forms and the interviews made with the students shows that the students with special needs have improved their skill levels.

It has been seen that there is also an improvement in the skill levels of the students with no special needs who participated in the SEM season. When the perceptions and participation of Russian students in the sport education season were examined, they emphasized that the new tasks and responsibilities were interesting and enjoyable. They talked about strong relationships, being cooperative and an enjoyable season. Due to the improvement in their basketball skill levels, it resulted that they did not bored, in contrast, basketball has become attractive even if the season took a long time (Hastie \& Sinelnikov, 2015).

In the studies including the teacher views, it has been shown that there is no sex-based difference, the students with high skill levels have high learning outcomes and, in some studies, the students with low skill levels have high learning outcomes according to the learning outcomes considering the student skill levels (Romar \& Hastie, 2016).

The studies carried out support this research result. In Fittipaldi-Wert's (2009) study on the SEM experience of students with visual disabilities, the students with visual disabilities have explained that, at the end of the SEM process, their skills have improved, being a team has strengthened them in terms of skill levels and their self-confidence on knowledge and skills in various sport branches has boosted.

Theme-2. The students' opinions on their non-playing roles: According to the findings of the study, most of the students with special needs stated that they fondly/willingly fulfilled these roles, maintained their roles outside the school and could have the same ones again. Presse et. al (2011) stated that the students with special needs can take many roles in the SEM like their peers, however; the students with autism, mental or visual disability may have more difficulty in coaching role. In this study, as Presse et al (2011) suggested, a non-disabled student and a student with mentally retardation have practiced co-training together in one of the teams, and its positive influences have reflected to the findings of the study.

Foley et. al (2009), stated that the SEM was effective in creating an environment including all the students in the classroom, and that the students are using their skills required for the player or non-player roles in their daily lives as well. They have explained in their studies that giving non-playing roles aside from playing roles to students with special needs within the SEM may increase their participation and enthusiasm towards various sport branches (Foley et. al, 2009). Likewise, these results, this study has also demonstrated that the students with special needs have a tendency to maintain their roles out of the class. For instance, the fact that the student with special needs who has the role of first aid specialist wanted to intervene in case of a crash out of the class is a sign that her effort to maintain her role out of the class.

Theme-3. The relationships of the students with special needs with their teammates: The students with special needs expressed that it was exciting to be in a team, it required responsibilities and their teammates, particularly the trainers and captains, gave more attention to themselves in and out of the school. The other students who have the roles of trainer or captain stated that they improved their coaching and leadership skills while developing their friends' skills.

Presse et. al (2011) expressed in their studies that other students were helpful in developing empathy towards them in the inclusive classes of the SEM. It is thought that the study results are alike considering the participating class is an inclusive class and the other students have socialized more with the students with special needs in following weeks of the model. Besides, Foley et. al (2009) indicated that the SEM provided leadership experience for all the students in refereeing, coaching, managing, captainship or narrating. Once again, according to the findings of this study, it has been seen that the individuals particularly in the roles of trainer and captain experienced leadership.

\section{Conclusion and Recommendations}

In conclusion, the SEM is a great opportunity for students with special needs to get involved in the social circle with the inclusive classes in and out of school. It has been seen that the SEM has a positive influence in giving active roles to students with special needs in a team considering their skills and interests, in their active participation to lesson, and in their motivation and socialization. In order for this change to take place, the teacher made some changes/adjustments in the lesson using scientific data collection methods and recorded the entire process. The critical discussions made with the expert were also effective in the process of data collection. In addition, the changes made considering the student and raising awareness in other children are the other findings of the study. We also witness with this study to the process of professional development of a physical education teacher with a new modeling experience using the action research method. 


\section{References}

Alagül, Ö., \& Gürsel, F. (2014). From"talked about" ideas towards "actioned" practices in pedagogical innovations. Book of Abstracts of 13. International Sports Sciences Congress, 156-157, Konya, Turkey.

Araujo, R., Isabel, M., \& Hastie, P. (2014). Review of the status of learning in research onsport education: future research and practice. Journal of Sports Science and Medicine, 13, 846-858.

Çelen, A. (2012). The effects of volleyball classes taught through sports education model on cognitive, affective and psychomotor achievement skills of students. Abant Izzet Baysal University. Unpublished doctoral dissertation. Retrieved from YÖK Tez Merkezi.

Doğu, S., \& Altay, F. (2010). The effect of sport education model on development of rhythm skills in dance education. Book of Abstracts of 11. International Sports Sciences Congress 192-193, Antalya, Turkey.

Doydu, İ., \& Çoknaz, H. (2013). The influence of sport education model on middle school students during extracurricular football studies on cognitive- psychomotor and game performance levels. International Journal of Human Sciences, 10(1), 925-958.

Doydu, İ., Çelen, A., \& Çoknaz, H. (2013). The effect of the sports education model on the attitudes of students towards physical education and sports. E-International Journal of Educational Research, 4(2), 99-110.

Fittipaldi-Wert, J. (2009). Effects of a sport education curriculum model on the experiences of students with visualim pairments. Palaestra, 24(3), 6-10.

Foley, J. T., Tindall, D., Lieberman, L., \& Kim, S. Y. (2009). How to develop disability awareness using the sport education model. Journal of Physical Education. Recreation \& Dance, 78(9), 32-36.

https://doi.org/10.1080/07303084.2007.10598096

Glaser, B. G., \& Strauss, A. (1967). The Discovery of Grounded Theory. Chicago: Aidine.

Hastie, P. A., \& Sinelnikov, O. A. (2015). Russian students' participation in and perceptions of a season of Sport Education. European Physical Education Review, 12(2), 131-150. https://doi.org/10.1177/1356336X06065166

Ince, M. L., \& Hunuk, D. (2010). Experienced physical education teachers' use and perceptions of teaching styles during the educational reform period. Education and Science, 35(157), 129-139.

İnce, M. L., Cengiz, C., Ebem, Z., Hünük, D., Kangalgil, M., Saçlı, F., ... Yapar, A. (2010). Sport education model. In Demirhan, G., Ince, M. L., Koca, C. \& Kirazc1, S. (Eds.), Instructional Models and Current Researches, (pp.47-88) Spor Publishing Company. Ankara, Turkey.

Koyuncuoğlu, K. (2015). The effects of gymnastics course taught through sports education model on students' cognitive, affective, and psychomotor attainment levels. Doctoral dissertation. Retrieved from YÖK Tez Merkezi.

Lund, J. L., Gurvitch, R., \& Metzler, M. W. (2008) Chapter 7: Influences on cooperating teachers adoption of model-based instruction. Journal of Teaching in Physical Education, 27(4), 549-570. https://doi.org/10.1123/jtpe.27.4.549

Lund, J., \& Tannehill, D. (2005). Standards-Based Physical Education Curriculum Development. Sudbury, MA: Jones and Bartlett.

MacPhail, A., Kirk, D., \& Kinchin, G. D. (2005). 'Sport Education in Key Stage 2 - Games', in D. Penney, G. Clarke, M. Quill and G.D. Kinchin (eds) Sport Education in Physical Education, London: Routledge.

Mertler, C. A. (2009). Action Research: Teachers as Researchers in the Classroom (2nd edition) California: Sage Publications.

Metzler, M. W. (2011). Instructional Models For Physical Education (3rd edition). Scottsdale, Arizona: Holcomb Hathaway.

Metzler, M. W., \& McCullick, B. A. (2008). Chapter 5: Introducing innovation to those who matter most- The P-12 pupils' perceptions of model-based instruction. Journal of Teaching in Physical Education, 27, 512-528. https://doi.org/10.1123/jtpe.27.4.512

Miles, M., \& Huberman, M. (1994). Qualitative Data Analysis: An Expanded Sourcebook. London: Sage.

Mills, G. E. (2011). Action Research: A Guide for the Teacher Researcher (4rd edition). Boston: Pearson.

Mohr, D. J., Townsend, J. S., \& Pritchard, T. (2006). Rethinking middle school physical education: combining life time leisure activities and sport education to encourage physical activity. Physical Educator, 63(1), 18-29.

MoNE, Ministry of National Education (2013). Secondary School Sport and Physical Activity Course Curriculum. 
Ankara.

Presse, C., Block, M. E., Horton, M., \& Harvey, W. J. (2011). Adapting the sport education model for children with disabilities. Journal of Physical Education. Recreation \& Dance, 82(3), 32-39. https://doi.org/10.1080/07303084.2011.10598595

Romar, J., \& Hastie, P. (2016). Teachers' learning experiences with the sport education model in physical education. Scandinavian Sport Studies Forum, 7, 1-26.

Siedentop, D., Hastie, P. A., \& Van Der Mars, H. (2011). Complete Guide to Sport Education. Human Kinetics: USA.

Tindall, D., \& Foley, J. (2011). Assessment modifications for students with disabilities in sport education, Journal of Physical Education, Recreation \& Dance, 82(7), 30-37. https://doi.org/10.1080/07303084.2011.10598655

Vidoni, C., \& Ward, P. (2009). Effect of fair play instruction on student social skills during a middle school sport education units. Physical Education \& Sport Pedagogy, 14(3), 285-310. https://doi.org/10.1080/17408980802225818

Wallhead, T. L., \& Ntoumanis, N. (2004).Effects of a sport education intervention on students' motivational responses in physical education. Journal of Teaching in Physical Education, 23(1), 4-18. https://doi.org/10.1123/jtpe.23.1.4

Wallhead, T., \& O'Sullivan, M. (2005). Sport education: Physical education for the new millennium? Physical Education and Sport Pedagogy, 10(2), 181-210. https://doi.org/10.1080/17408980500105098

\section{Copyrights}

Copyright for this article is retained by the author(s), with first publication rights granted to the journal.

This is an open-access article distributed under the terms and conditions of the Creative Commons Attribution license which permits unrestricted use, distribution, and reproduction in any medium, provided the original work is properly cited. 